\title{
The Politics of Space: A Reflection on Remapping
}

\author{
Ian A. Bethell-Bennett \\ English Studies \\ University of The Bahamas
}

\section{Epigraph}

Sea bathing shall be permitted at or from the public property between the western

boundary of the British Colonial Hotel and Nassau Street between the hours of 9 a.m. and

12 noon and 4 p.m. and 6 p.m. only ("Sea Bathing Rules," 1938).

Finally we're inside

The gated community

Finally with Massa inside

The gated community

Savages singing the blues

Safe within the pink wall (Manoo-Rahming, 2010, p. 79).

\begin{abstract}
Place and space are vital ingredients to Caribbean success in tourism. Space and how we live in it is historically and politically or geopolitically determined beyond our lives. The Bahamas and Puerto Rico share a particular resonance as their spaces are being repacked and recommercialized as parts of an elite geographical zone where the rich come to play and stay but avoid the crowds. So, public spaces, the coast and beaches, are being taken as privately owned and rezoned spaces for high-end enjoyment. In the last two decades, this privatization of space has taken over in Puerto Rico and The Bahamas in disturbing and interesting ways. Many locals buy into the offer of jobs in exchange for international development or Foreign Direct Investment as government eases its way out of governance in the wake of climate-change-powered super hurricanes and the resultant green gentrification. So, while small coastal communities succumb to the dream of progress couched in land sales and increased land prices, local access to regular lives disappears under high-end gated communities and private islands.
\end{abstract}

\section{Introduction}

The very space we take for granted as open, accessible and un-barriered - the beach, the coast, public squares and esplanades-have become mined with meaning and limitation. One would think that one could walk onto and enjoy a public beach and its water at any time. However, the Sea Bathing Rules of
1938 speak to a reality that is often overlooked in this former colony. Although the Sea Bathing Rules and a number of these regulations have been reformulated, they speak to a control on space that continues through majority rule and independence. These regulations lay the foundation for our continued practice of limiting locals' access 
to beaches and public spaces in general. If the public beach is only accessible at certain times and based on certain stipulations: "All bathers shall be properly attired to the satisfaction of the Commissioner of Police," then space is hardly public or free.

In many colonies, space was first seen as blank or open until Spain or Britain, for example, arrived. (This idea usually meant that the land was seen as theirs for the taking; they could own it simply by imposing their rule of law over it). The land was dominated first by the crown and then by ruling parties. In many places this changed from the 19th century when more Blacks and browns owned land, say for example Trinidad or Jamaica, and the early and mid-20th century when the land had been reclaimed by colonials.

I chose the two epigraphs because they contextualise today's spatial struggle. Historically, many gated or middle-class and elite communities were not open to Black ownership, but since emancipation and later legal changes, these racial stipulations were eased though the financial and class requirements were not. The fact that Blacks are now behind the walls, though in limited numbers and often disempowering others outside those walls, suggests that Blacks serve as the new colonial masters. This depoliticises the stigma of racial segregation and assumes that the former colonial place was emptied of colonial laws, regulations and spatial politics upon achieving majority representation and so-called universal suffrage.

This reflection explores Puerto Rico, a nonindependent commonwealth of the United States, and compares it with an independent, sovereign state, The Bahamas. It focuses on the ways in which native Puerto Ricans and Bahamians - particularly those of African descent - are spatially disenfranchised by development. This reflection understands that the complexities around land and space existed prior to tourism, but that tourism has further complicated an already obfuscated and challenging situation. As Smith (2007) points out, this relationship that predates postcolonialism is deeply troubled by a late capitalist expansionist move to acquire more land in the tropics. This trend is visible in The Bahamas and Puerto Rico. The processes for doing so may be distinct, as one is offshore but not internationalnotwithstanding that many United States institutions treat Puerto Rico as international - and the other is international and offshore.

Smith's work provides an interesting and important entry point into the discussion, but my point is far more common than hers. Yes, it must be taken as given that most local communities in The Bahamas cannot afford to compete with Foreign Direct Investment and the prices they create, but the disaffection or fracturing is deeper and far more nuanced than that. It is the passive and unobtrusive possibility of gentrification and the gentle claw back of advances made during the heyday of so-called Black Power during the 1960-70s that is deeply troubling. A part of this is the discussion to provide initiatives for poor, Black Over-the-Hill communities to benefit from economic policies often extended only to foreign direct investment businesses. When one grows up in a space defined as ghetto and lacking in basic services, one begins to see oneself as embodying such promise.

In this study, I explore how dispossession occurs and how discourse around belonging and un-belonging that serve particular agendas and indeed normalise removing public land from the commons and gating it off - as can be clearly evidenced in the discussion in the Save Guana Cay Reef case-are developed and deployed. This 
study does not pose academic questions about space, but rather attempts to discuss it through lived experience and reflecting on the shifts that have occurred. This is really a narrative of trying to understand how indigenous cultures can be dispossessed, disaffected and disenfranchised without them really understanding this is on the agenda until it is almost too late. This study arises from my experience living and working in both spaces and grappling with understandings of spatial and place dynamics that are complex and almost incomprehensible on some levels, but simplistic and mundane on others. In The Bahamas, on New Providence, a relatively small Bahamian island for example, people can argue that they do not know or care about what happens outside of their immediate spatial zone. So the promise of a New Riviera (a slogan used by the original Izmirilian Baha Mar) on Cable Beach is alluring, and a gated community that hopes to expand to absorb a great deal of the southwestern quadrant of the island is beguiling.

\section{Puerto Rico as baseline study}

In Puerto Rico, meanwhile, people care about the politics of space, but often do not know what is afoot until it becomes common knowledge. For example, in the cases of Paseo del Caribe and then Nuevo Riviera del Caribe, both of these developments occurred on federal land owned by the United States armed forces and later returned to Puerto Rico. But, they never became public or were truly returned to the commons. A similar statement could be made of The Bahamas, but this work examines more closely the de facto fallout from and impact of the privatisation of space and the spatial dynamics this enacts.

As swaths of land are sold to international companies to create all-inclusive communities and resorts, these spaces become out of reach to local communities, even when they may encroach on traditional lands and access to ocean and farming land. There seems to be an operating metaphor and ethos which argues that if you can't join in, then don't criticize-just accept the reality of the world. But space and spatial justice are more significant and salient than that as the spatial reorganizing of place means the separation of parts from the whole (Harvey, 2002; Soja, 2010; Low \& Smith, 2006). The relationship allows certain ideas to be galvanized in terms of minorities not needing access to sporting facilities and open spaces, while others, given their reduced access to education, have increasingly reduced or declining access to success because race is undertoned by failure and limited access: working class Negroes don't play golf or tennis.

The Puerto Rican case of resistance to San Jeronimo being taken from the commons demonstrated more political activism and public awareness than most of the land grab cases in The Bahamas, except the early Clifton Cay and Bimini Bay projects (Dames, 2002; Robinson-Blair, 2005). Puerto Rico provides a very interesting and instructive comparison point for what is afoot in The Bahamas.

We imbue space with value and meaning, and the coloniality of space is very much a consideration in former colonised places when it comes to value. In colonial times, Negroes were allotted the least valuable land for their dwelling places, while settler colonies and plantations received the best land. The value of land was also relative: marshy coastal land was seen as undesirable and a space that could be allotted to Negro settlements, in part because of mosquitoborne diseases prevalent there. Similarly, beachfront on almost every island was considered worthless land (except for 
cemeteries) until after the mid-20th century. The exact dates differ for every island. The value accorded to coastal/beachfront land was determined by the external or foreign gaze rather than internal use or requirement. As the coast became more valuable, many communities then inhabiting coastal areas were under threat of erasure through development schemes that valued closing off the coast through marina, resort and golf, tennis and country-club gated community zoning. This exercise has been particularly aggressive in the late 20th and early 21 st centuries.

The fight over Fort San Jeronimo, between San Juan and Condado, is one example of this. Rather than it returning to the commons after the United States Marines left their base that had included said Fort, it was turned over to a private company that then gentrified it with high-rise buildings, high-end condominiums and exclusive restaurants and shops catering to a top five percent, while the Fort was kept locked. The legal battles were fierce and the occupation of that space by Puerto Ricans trying to keep open spaces and public patrimony public was equally fierce. Sadly, those battles were lost as the space was closed off to all but those who could afford to pay to play and those who could pass through but not stay. It became Paseo Caribe. The Fort itself remained locked off from most locals, a space for cocktail parties and weddings. The attitude spoke to what would later develop into the debate about "such is life," uttered by Puerto Rican developer Jaime González.

As place and space become commodified, so does the very culture of Puerto Rico. Visitors are encouraged to consume Puerto Rico in interesting ways. Meanwhile, areas like Condado and Old San Juan are cleared of their poor and Section 8 residents and North Americans buy up land and restore old colonial buildings. This moves all aspects of Puerto Rican culture out of these spaces and further into the interior. The entire notion of Pan, Tierra y Libertad used to promote Puerto Rican independence was co-opted into a drive towards commonwealth status. So, for example, as working-class Puerto Ricans move into the cities, the rural paradigm shifts. Industrialisation, through Operation Bootstrap or Manos a la Obra, changes the entire relationship with land and home. This is further developed under the neoliberal policies of San Juan Mayor Jorge Santini and Governor Luis Fortuño when the land grab/gentrification really gathered force and took over spaces exponentially.

My experiences in Puerto Rico made me aware of the shifting spatial class relations that had not been so evident in The Bahamas; though the latter had more tourism development and far more exclusive clubs and resorts, they were usually on different islands and on a much smaller scale. Once I had to grapple with being charged for beach access and with realising that if I lived in an area like the coastal town of Fajardo, where the suitably-named El Conquistador Hotel dominates the cliff, water would be used by the resort leaving the surrounding community without service for weekends and holidays, periods when the resort was full, the awareness was more acute. These communities slowly became too expensive for locals. This opened my eyes to similar trends in The Bahamas, especially on New Providence and islands like Harbour Island.

Puerto Rico then becomes a jumping off point from where I can study spatial relations in The Bahamas. Bethel (2000) does a great deal of this in Chapter 4 of Navigations. In The Bahamas, similar fights have been had, yet the great majority of the population live in ignorance of the struggles: 
from the fight to overturn the proposed Clifton Cay development, a victory for the people at the end of the 20th century, to the silent passage of Albany after developers learned lessons from the former debacle. On Bimini, Abaco and other islands from Mayaguana to Ragged Island, different types of spatial reconquering have been engineered by a distancing of the commons from the populous and legitimising discourse. The discourse of empowering Foreign Direct Investment through land grants and concessions has been normalised and modernised so that the hook is jobs, yet more of the workers to build the projects are imported on temporary work permits. This has slowly eroded spatial relations. Bimini Bay was a most notable site of such controversy as mostly foreign workers were brought to the island as Bahamian labour was scarce.

While we think of the beach as public space, the increasingly privatized nature of much of the coast signifies that this thought is already undermined by a divergent reality. Space and its use bifurcate because it is one thing to be able to walk across land to the beach, but another to have to circumvent private property in order to attempt to access a swimming spot. Of course, these are all questions that cannot be answered completely here, but they evoke thoughts and challenges to presumed normalcy of the idea of spatial (in)justice and what I want to call social (in)justice that intersect here. The manner in which one inhabits space, the space one is allowed to inhabit and the colonial legacies of that space, the hostility to blackness within that space, are all matters that really show themselves in the way we traverse space in the postcolonial world. Perhaps a salient example of this is when Albany began its development in the early 2000s and suddenly an entire roadway was cut off from local access and the road moved from close to the coast to what is now the Frank Watson highway (see Figure 1). Many Nassauvians living in the middle and eastern parts of the island, for one reason or the other, had not noticed this shift. They had not noticed space being policed away from them.

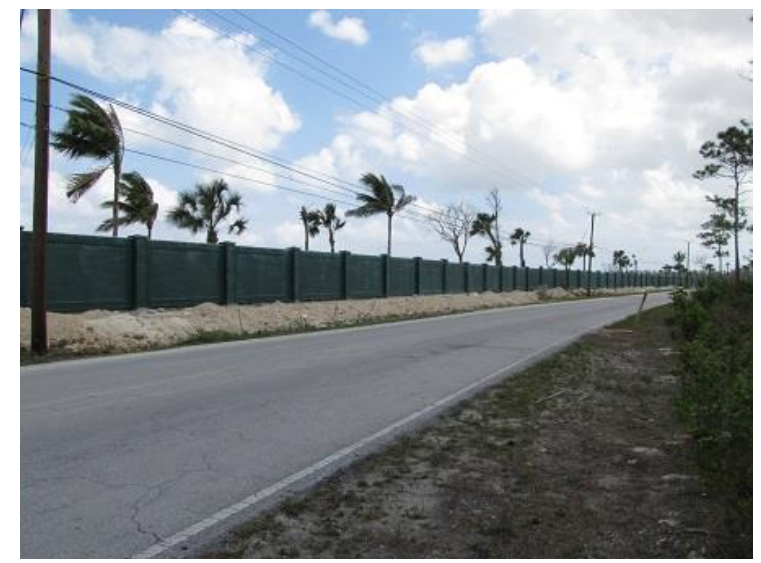

Figure 1: The fences of Albany.

The control of space and policing of access to public spaces is seen in Section 4 of the Sea Bathing Rules that all bathers be properly attired and the politics of respectability remain steadfastly entrenched in the postcolonial place. In fact, many public spaces are almost completely closed off from them and offices that serve the public, though peopled by them, argue that appropriate dress will determine access, but any attire appropriate to the tropics will render one inadmissible. Space, over place, is controlled by strict adherence to appropriateness of attire and behaviour. This way of excluding is class- and racebased and often used to keep people in their place. Bethel alludes to this in her Navigations (2000) as does Saunders in Race and Class in the Colonial Bahamas (2016) - though they do not challenge the concept of exclusion through appropriateness directly, they do demonstrate how narrow the structures of acceptable comportment are. This carries over into the ways in which Bahamians are 
allowed to use public spaces and the ways in which common space is constructed. If one dresses a certain way that may be in keeping with the climate, one should not be granted access to spaces. This approach was clearly evident during the late 1970s and 1980s in Nassau, in particular, as Rastafarians were often barred from public spaces or entertainment venues. Even after Majority Rule and Independence there remains a stark barrier of acceptability and respectability around race and gender identities that see certain spaces as closed off to people of a darker hue. Further, women's dress is always informally policed by groups such as security guards and receptionists. This is also seen in the way, as Strachan (2002) demonstrates, private resort and tourist spaces are policed against darker-skinned people.

The Bahamas Ministry of Education continues to police people's appropriate colonially-approved attire, notwithstanding independence. That is further complicated by laws and initiatives that empower offshore investment in paradise more than onshore investment. Even though the guard has changed, spatial politics and beliefs remain in play. There was arguably a period when the laws seemed to have been relaxed so that all Bahamians and Puerto Ricans could have aspired to greater spatial justice, empowerment and individual/community success, but that was quickly eroded by a new kind of colonial spatial relation that redeploys those old colonial ideals and practices in new ways. So, for example, in The Bahamas, while space was certainly segregated during colonial and United Bahamian Party rule, efforts and advances made by Blacks and through White paternalism to allow the creation of open spaces and allow Blacks entry into public spaces such as golf courses and tennis courts, shifted the paradigm and relations.
After Majority Rule in 1967 and especially into the 21st century, those spaces were repackaged as exclusive sites for tourist enjoyment and the spatial divide was gently reestablished. This is similar to the Santini Fortuño combination that galvanized energies behind gentrification and selling this to local Puerto Ricans as the normative way to live, the energies had been building during the early 2000s. Development began to be focused on gated communities, the tourist coast that has been almost entirely removed from easy sight from the road, as Bethel discusses of Bay Street which she argues was originally built along the coast. Much of Over-the-Hill has been left to its own devices as the focus remained on Paradise Island, Cable Beach, Lyford Cay and Old Fort Bay. The old hotels that once stood on the Nassau side of the Paradise Island Bridge have mostly since closed, leaving only a few guest houses and many derelict buildings. Hotels such as the Glen Eagles, Pilot House, Montague Beach, Royal Victoria have all disappeared and the land redeveloped with few visible signs of Bahamian history.

The Blue Hills Sporting Complex, developed for Blacks during the heyday of the international Black Power movement, was effectively abandoned by majority rule government shortly after independence. Golf has become too expensive for most Bahamians though there are some groups who work to provide access to golf camps and clinics for working-class Bahamians. Many courses are either within gated communities, resort properties or require membership. This has led to the reexclusivising of the sport, notwithstanding that the young Black and brown Bahamians who pushed for majority rule and independence benefited from access to these "elite" sports.

The spatial dynamics, I think, and, this is a 
point my work around space makes, have been overlooked by many because of a lack of historical knowledge of spatial relations; the wide generational gap between those who struggled and did not talk about it and their children or grandchildren means the latter are no longer aware of the challenges faced, gains made, and losses encountered. Hardships and gains were muted by discontinuity through no community dialogue or story.

The spatial relations after majority rule in The Bahamas and what I witnessed in Puerto Rico since the 1990s was a slow creep of privatising public space/the commons. In Puerto Rico, though arguably public, beaches became sites people had to pay to access or they could access only at particular times. New Providence had not created gated public beaches per se, though access to the coast was made even harder as spaces like Old Fort closed off what was Lightbourn Creek. This is different once one crosses the Paradise Island Bridge.

The debate around Paradise Island beaches in The Bahamas is unique and problematic given that there is a complex relationship between public and private space as public access to the beach has been cut off by privately-owned land. Other beaches and fishing areas were gated off though officially still allowing passage over private land through public access points. These have become increasingly polemical as they are poorly maintained or the rights or easements have been extinguished. (Figure 2). Beach and coastal access in these places were and are important because many communities are seafaring communities that depend on coastal access. As these spaces become smaller and less easily accessible, these communities change and/or die.

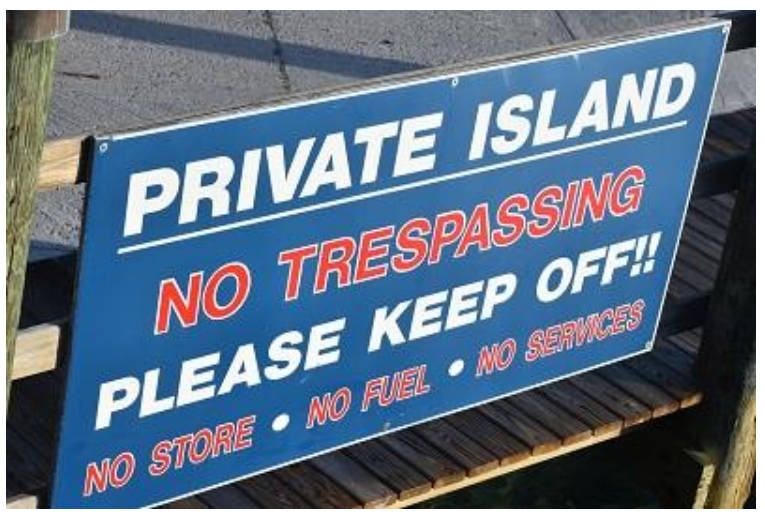

Figure 2. Private island sign.

\section{Theorizing space}

Perhaps space in the colonial context must be first contextualized by Fanon's distinction between the settler space and the native quarter.

The colonial world is a world divided into compartments. It is probably unnecessary to recall the existence of native quarters and European quarters, of schools for natives and schools for Europeans; in the same way we need not recall apartheid in South Africa. Yet, if we examine closely this system of compartments, we will at least be able to reveal the lines of force it implies. This approach to the colonial world, its ordering and its geographical layout will allow us to mark out the lines on which a decolonized society will be reorganized (Fanon, 1963, p. 37).

This organization, during colonialism, was clear and so could be resisted. This resistance to spatial delimitation and racism was obviated by the struggle for suffrage and to own land, to change the rule from voting that hinged on a man owning land and one man having the opportunity to vote in as many places as he owned land, as was the case in colonial Bahamas.

Spatial organization then is determined by class and race before independence and is later deconstructed by the removal of the 
obvious difference between races/colours, which was in itself a class marker (Saunders, 2016). Fanon continues:

The town belonging to the colonized people, or at least the native town, the Negro village, the medina, the reservation, is a place of ill fame, peopled by men of evil repute. They are born there, it matters little where or how; they die there, it matters not where, nor how. It is a world without spaciousness; men live there on top of each other, and their huts are built one on top of the other. The native town is a hungry town, starved of bread, of meat, of shoes, of coal, of light. The native town is a crouching village, a town on its knees, a town wallowing in the mire. It is a town of niggers and dirty Arabs (1963, p. 39).

Fanon's observations can be read in tandem with more recent critics who challenge the way space is organized and how social justice is determined by spatial organization. Fanon establishes that:

The settlers' town is a strongly built town, all made of stone and steel. It is a brightly lit town; the streets are covered with asphalt, and the garbage cans swallow all the leavings, unseen, unknown and hardly thought about. The settler's feet are never visible, except perhaps in the sea; but there you're never close enough to see them. His feet are protected by strong shoes although the streets of his town are clean and even, with no holes or stones. The settler's town is a well-fed town, an easygoing town; its belly is always full of good things. The settlers' town is a town of white people, of foreigners (1963, p. 39).

This paradigm has been bifurcated in the 21 st century, as argued above, by the clear distinction between local and tourist areas. On New Providence, new developments like the promised boardwalk from Western Esplanade to Bay Street (that has been sold to Chinese investors) boast high-rise buildings and footpaths that access restaurants and bars compared to the Overthe-Hill communities where rubbish collection is minimal and many homes still do not have indoor plumbing. Public space has been diminishing as can be witnessed by discussions around the right to the city and social justice in the city. Harvey and Soja, along with Low and Smith among others, work with making the city more spatially just where people have access to the city and access to social justice, public transportation, education, open spaces, for example.

Conversely, when people do not have access to public space or to spatial justice, we find that they have limited social justice. As Soja underscores:

Thinking about space has changed significantly in recent years, from emphasizing flat cartographic notions of space as container or stage of human activity or merely the physical dimensions of fixed form, to an active force shaping human life. A new emphasis on specifically urban spatial causality has emerged to explore the generative effects of urban agglomerations not just on everyday behavior but on such processes as technological innovation, artistic creativity, economic development, social change as well as environmental degradation, social polarization, widening income gaps, international politics, and, more specifically, the production of justice and injustice (Soja, 2009, p. 2).

Perhaps these concepts are best combined with Galtung's theories of structural and cultural violence, because structural violence 
is often used to limit or deny one access to spatial and social justice. In Over-the-Hill communities, the linkages between this and spatial or social injustice seem clear. Soja argues,

In the broadest sense, spatial (in)justice refers to an intentional and focused emphasis on the spatial or geographical aspects of justice and injustice. As a starting point, this involves the fair and equitable distribution in space of socially valued resources and the opportunities to use them $(2009$, p. 2).

This is also compounded by the closure of public spaces, or Fanon's settler zones, mostly occupied by hotels, high-end condominiums and gated communities.

Further, the reframing of space into more respectable areas of glitz and glamour results in areas being abandoned and others being defined as ghettos. Fanon, Said, Harvey, Soja and Low and Smith all explore the ways spatial relations determine how successful people can be. Further, Galtung's theories of cultural and structural violence (Galtung, 1969) argues that people are kept from living up to their potential by inequality. It is most telling, though, when the study of space reveals that simple public transport can resolve many problems of access, as Soja (2010) and Harvey (2002) both indicate the need for spatial justice and the impact this has on individual success.

So, remapping, re-scaping, as has been discussed in my other work, examines the physical re-scaping of the space so that it resembles another exotic place (BethellBennett, 2010-11). The local space is changed and rezoned so that international businesses can come in and set up shop moving local cultural markers, trees and historical sites, as can be seen from Nassau's Colonial Hotel and the site of Fort Nassau, now owned by Chinese interests. This discussion of rezoning is also dangerous as can now be seen with the Over-the-Hill rezoning and economic zone initiative that could result in gentrification by pushing out the poor people who have inhabited these spaces in favour of business expansion. The old businesses and services that once inhabited Over-the-Hill have been erased through various shifts in power, especially as the Black middle class left this racially determined spatial zone for the prospects of success in an expanding urbanized island.

This development has been experienced differently on Guana Cay, for example, where many of the original families have been encouraged off the island through the aggressive expansion of the high-end gated community and resort. The commons, where traditionally these people fished, crabbed and farmed, now lay behind fences. Similarly, on New Providence, much of the coast has been made private through spatial reclassification or closure by resorts, gated communities and condo complexes that result in temporary unrest, but people return to their daily routines because they are hardpressed to survive.

\section{Thinking history}

As a child, I assumed that everyone had access to space and could enjoy open spaces and the beach. I learnt that this was false. Many people remained locked in historical boundaries that saw certain areas as out of bounds to them. The colour bar remained unbroken in their minds. I have found this particularly so on New Providence with a younger generation of students who, for example, do not think of spaces "out west" as being accessible to them because they are too far. Moreover, these students were mostly born in the last decade of the 20th century and so much of the sectoring off of access to areas such as Albany would have been well under way (Figure 3). It is 
significant that many young Bahamians, unlike in Puerto Rico, seem to not understand their right to access public space and the historical fights for the same. However, what I find most challenging in today's information age with the compression of time and space, is the lack of knowledge of rights and access and the shrinking space open to public use and enjoyment. I see this access being effectively and progressively eroded where there is little awareness of the claw back to private ownership and a new discourse around gated communities that is no longer racially charged, but couched in terms of international elitist ownership. I have taken much of this from discussions with students and others in the general community as well as my own experience as an active participant in outdoor activities that have allowed me to run, cycle, or swim around places that have historically been out of bounds to many or have become off limits through more recent privatization.

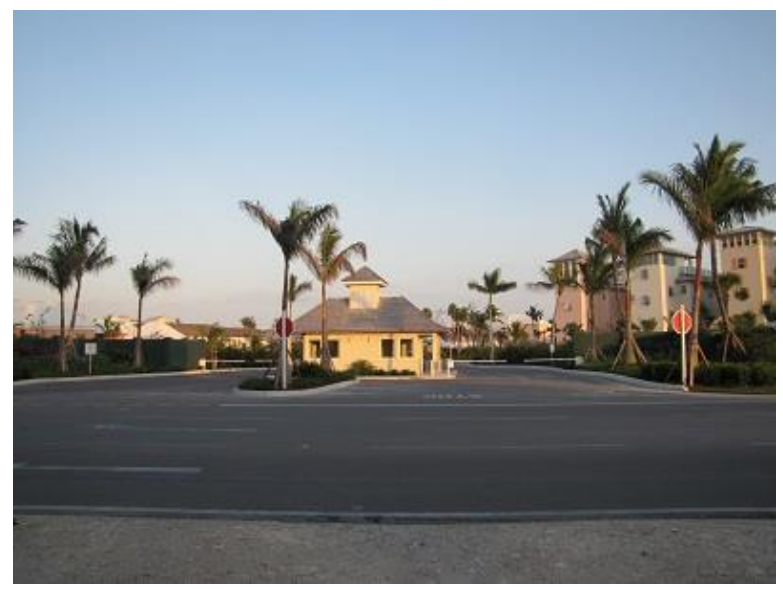

Figure 3: The gatehouse of Albany development.

The discussion as couched by Fanon and other theorists has been missed in many of our small island communities. That is to say, the debate about Blacks not being allowed in settler communities has now shifted. Space is often overlooked for other important considerations like place or perceived power. The way people are encouraged or allowed to inhabit space is not really explored in much of Caribbean studies. In fact, the way Caribbean space has developed of late has been largely overlooked except by those investigating from outside. Freitag (1994) discusses this shift of spatial justice in the Dominican Republic as tourism development displaces local landowners. His work can be seen as a precursor to Bethel's thesis on the importance of land to identity formation and to the work of Momsen (2005) and Baldwin (2005). Many of these show how fraught spatial relationships are in the Caribbean as old colonial legacies of race and class stratification and demarcations continue to work.

The recent debacles around depopulation and land value increase that disallows local ownership has not received much attention except, perhaps, by local community groups. However, the re-scaping that Thompson (2006) explores, though very timely, also needs to be widened, which is where I see my examination fitting in. While my spatial explorations take Thompson's work as a point of departure, they also extend the conversation beyond the image of the region to how space is conceptualised in terms of how people who live there value it and how they are encouraged to see their relationship with it. So, for example, there are discourses of spatial identification that circulate an image of darker-skinned Black people in The Bahamas, particularly on New Providence, inhabiting what has come to be termed the ghetto, the traditionally Black, middle-class neighbourhood Over-the-Hill. People who come from this space, though most of the very successful Black families hailed from there, are referred to by those same people now in political power as thugs and threats to national security (Bennett, 2014). So, place and how people are seen in that place are important to the discussion as 
well as to new discourses and imaginings often informed by colonial ideals/ideas which define that place as exotic, offshore and empty of other bodies except those who come to occupy it temporarily.

The colonial relationship with space has been entrenched by the late capitalist, neoliberal, postmodernist, post-majority rule globalised ethos of life in the Anglophone Caribbean. Césaire (2000) explores some relationships with space as he once again does in poetics of relation. Glissant (1989) discusses the connectivity, the rootedness and the rhizome of Caribbean relatedness, but this, I think, can be used in conjunction with other more geography-based understandings and conjourings of space and spatial justice as elaborated by Soja and Said - the latter of which argues that space is already imaged into being by the colonial power or the West, though not always the same, often elided (Said, 1978). However, in this case, this bloc comes to determine how the Caribbean, for example, mapped or imaged into being, especially since the crash of 2008. These theorists, along with Fanon, articulate the power of dominant/colonial discourse and mapping to define place and space and those native people who inhabit it. They are rendered inferior through art and literature and the concept that they should be grateful for gated communities that popup on their (I)lands.

This power to inscribe, describe, map and image, though apparently overthrown at the end of colonialism, as the above mentioned have intimated, remains oddly intact. This power is an important concept as it undergirds any discussion around access and spatial justice. So the concept of spatial justice means that there is power to use space and this power is open to all people. Moreover, the idea of social power, or one's ability to empower oneself notwithstanding where one lives, goes to school, plays and dreams, is equitable and just for all. These concepts, however, are undermined by the spatial power of the former empire and the continued control through indirect colonialism. Those who inhabit the former colonies are no longer able to see the obvious spatial differences between settler and native quarters because those in political power look like the people who inhabit the native quarters, often referred to as such even by this political elite. The real economic power to map, image and define, though facilitated by the local elite, resides offshore (Bethell-Bennett, 2016).

I understand-given the historical and geographical redetermination of spatial relations - that spatial justice as a concept and then as a lived reality is complex and complicated in the Caribbean context, but also in any first people's spaces. Firstly, because the land was already colonised by the time the new settlers arrived-and secondly, many Caribbean territories or countries even after colonialism ended-it passed into a new phase of management that was outside of their sovereignty. This is even more complicated in the case of Puerto Rico: a territory/commonwealth of the United States that passed from Spanish to American hands in 1898, even as it was 'winning' some degree of autonomy from Spain. Some of the more revelatory discussions about policy and spatial (in)justice are perhaps had in works on tourism as Cocks' Tropical Whites (2013) and Skwiot's The Purposes of Paradise (2010). These works explore the intricacies of policy and planning as they relate to the "destination" we now refer to as the Caribbean. They demonstrate clearly how fully space was taken out of the commons and created to be inhabited by visitors (Low \& Smith, 2006).

Space is extremely important, if not pivotal, to one's concept of self. If one feels at home 
in one's space, one tends to do better than if one does not. By disconnecting, either intentionally or through happenstance, a population from its home, one can arbitrarily or intentionally cause absolute or partial disassociation from the land/space. When resorts move in, they go further to enclose and lock of from the land many of the local communities. The Bahamas has become a space rife with examples of this. Guana Cay and Baker's Bay is one example. The shift on New Providence from Black empowerment to tourism and international land-ownership is another point. In Puerto Rico, there are many other cases, but there are two obvious points of entry, Old San Juan and Roosevelt Roads.

\section{Returning to the base: Moving through Puerto Rico as it gentrifies}

Of course, the situation has allowed government to impose on the citizenry dire and almost impossible restrictions and demands that are not shared with foreign concerns. In San Juan, El Caño Martín Peña has been the subject of discussion for years. It is a wetland area that exists as a lowincome settlement. For years this area has been governed by a trust, a fideicomiso, in an effort to provide residents with access to and rights over land. Jorge Santini, Major of San Juan between 2001 and 2013, along with Luis Fortuño, sought to remove the poor from San Juan and demolish old or rundown buildings that were not protected by el Instituto de Cultura which governs the colonial city and its immediate surroundings. One of the spaces on Santini's radar was the community in and around el Caño Martín Peña which did not own the land they resided on but, as stated above, had created a community land trust organization to protect their interests. This area, like much of San Juan, had been left to its own devices for a long time, but as the gentrification process took root and gathered steam, their claims were being challenged. Santini's answer was to separate and so undermine the efforts of the trust. He did this through providing some individuals with titles to their land which allowed them to commodify their dwelling spot. His intention was to allow these people to understand the value of their land by offering them money for what had always been touted as worthless. He could then convince them to sell and they would be able to "move up" - this would, in turn, pressure others to realize they had less support and so acquiesce to government's demands.

The project had taken slow start in Old San Juan and around what was earlier known as La Base on Isla Grande, which some part of was taken over as the Distrito de Convenciones in the first part of the 21st century. It had also been taken over before that by the Instituto de Cultura which passed it on to Public Works, which is how it was when I first encountered it in my 20s. This space had tennis courts, pools and wide spaces with old derelict hangers from when it was a base and other ruins, including the Miraflores Powder Magazine. What astonished me was how completely the space was transformed while I lived there, first as a student and then as a professor. In many ways it was like a slow creep that really was not that slow and not really a creep. The area between Old San Juan and Miramar/Condado had been totally altered with most of the low-cost housing projects removed and more up-market housing erected in their place. Shops like Gucci, Coach and others populate the new landscape. While the allure is obvious, the cash-rich reality for such places when one is deeply in debt or unemployed, as can be seen from the economic status of Puerto Rico, presents a huge disconnect.

Old San Juan similarly developed from being a community that had once been 
thriving and well appointed to a run-down community with all the local services and small restaurants a local living community used. By the end of the first decade of the 21 st century, many of the low-cost buildings in Section 8, as well as small mom and pop eateries and shops, had been transformed into rental condominiums. As a result, all of the workers who once resided there, many of the elderly and indeed local fixtures, were no longer seen. The community had been gentrified. Artists had moved into some of the sprawling old buildings and began to improve them. Then came mainland money and local and national developers and business people who invested in buying and updating buildings that were mere shells, though still protected by El Instituto de Cultura.

Gone were the old businesses and local shops; these were replaced by United States franchises and department stores such as Marshalls and tourist attractions. The flavour of the city changed; the life left, except for where those old-diehards had managed to stay in their space. This is not to romanticize the space as it was previously - indeed, there were massive and complex problems from water, electricity, crumbling buildings and traffic congestion. But the space was alive in a way that shifted after it became more expensive and touristy or boutiqued, pimped out. Meanwhile, as the cruise industry developed, the port took over much of the docks in front of Old San Juan while, on the other side of the once disconnected islet from the rest of the Puerto Rican mainland, stands La Perla, yet another space of resistance to gentrification. Old San Juan and La Perla had a relationship that allowed both spaces to thrive, one being famous for bars and clubs and the day-to-day of life as well as offices and the seat of government, the other being famous for lawlessness, drug dealing and shootouts, but family life and spatial power.

From time to time, the police would go in and occupy la Perla which would lead to an incredibly uncomfortable disharmony because everyone was suspect and the balance of no violence, mutual respect and symbiotic relations almost disappeared. Similar kinds of communities can be seen along the north coast of Puerto Rico, from San Juan through Piñones and Loíza to el Yunque and Fajardo. Many of these communities were or are poorer and reside almost precariously in what was seen as unfavourable land which later became extremely valuable, especially as tourism developed.

Efforts were made to encourage people to sell their land or it would be expropriated from families through such instruments as the Law of Imminent Domain. The recession which started early in Puerto Rico that saw government shutdown in 2006 began a process that undermined much of the fragile yet resistant development and land ownership without title. Sojourns along the coast would provide endless local colour and much of the Puerto Rican culinary classics, especially what is referred to as fritanga, alcapurrias, etc. These communities may remain, but their space has been reduced because the land has become 'too expensive' and progress development has taken over. Loiza and the surrounding area was mostly Afro-Puerto Rican, as el Caño was mostly poor.

Ultimately, these communities are under threat because their land is 'too valuable' for the residents; there is/was little governmental support for their continued existence. The idea is this space needs to be cleared, or the swamp needs to be drained, with no compassion for or understanding of community and land-based identity or even social justice. As Soja argues in Seeking 
Spatial Justice (2010), bus routes do not connect the poor in the city with the city. So, I could move more or less smoothly between Old San Juan and Rio Piedras along the tourist route in the more expensive Metrobus, but I could barely move around and through these other communities in the cheaper and less reliable AMA, which was usually packed with the poor and workingclass people who struggled around.

Since hurricanes Maria and Irma, of course, this situation has worsened, but the purpose of this essay is not to focus on the worsening impact of climate change that leads to disaster capitalism, but rather to explore the complexities and politics of the places we inhabit and how space determines how we live. Further, attitudes to that space and about the people linked to that space also determine how successful people can be or are. On New Providence the fight for space, the spatial demarcations though removed from the earlier period of segregation, remain steadfastly entrenched. The vocabulary of the vernacular also remains oddly similar to the olden days of racially divided spaces.

\section{Green gentrification or the post natural disaster land grab}

In the wake of the many hurricanes over the last few years, disaster capitalism and green gentrification have become almost commonplace. The language of dispossession is interesting as it is couched in a subtle, deracialised, though very racially charged argument that the people who inhabit these spaces are lazy and so did nothing to improve their lot. This discourse was seen in New Orleans after hurricane Katrina. It was also seen in 2005 in posttsunami Indian Ocean territories. Closer to home, it has been witnessed in post-Maria Puerto Rico and Barbuda as governments change laws that have allowed people to keep communal land ever since emancipation, in the latter case. To prevent the return of residents, the government of Antigua and Barbuda has argued that the island should be given over to an entity that is better able to manage natural disaster clean-up. The Guardian points out, "the government claims its aim is to speed recovery on the hurricane-devastated smaller island but Barbudans accuse it of a 'land grab", (Handy, 2018).

Meanwhile, at home, as government puts in place the Over-the-Hill revitalization plan, the discussion has also focused on depopulating Ragged Island. As The Nassau Guardian headline offers "Bannister: No money for Ragged Island restoration this budget cycle" (Cartwright-Carroll, 2018), which hints at a serious shift in the way redevelopment will occur. Little, though, has been said of the Chinese deconstruction and rezoning of the coast and Fort Nassau, which brings us back squarely to the debate around San Jeronimo in Puerto Rico. The Chinese construction company has locked Fort Nassau away from most Bahamians and the discussion around national patrimony has been silent. The promised boardwalk, the strength on which the Pointe project was arguably sold to the Chinese, will no longer happen, but the national historical patrimonial space has been consumed by a private owner, in fact by another state. (This matter requires its own lengthy discussion). Meanwhile, the greening of space is seen and sold as an international affair, not something to be managed or owned by Bahamians, as Gould \& Lewis (2018) point out:

the hurricane and subsequent disaster capitalism has shifted the locus of control over development projects from Barbudans to global elites. In the current global political-economy, climate change fuels greater inequality and a power shift 
from vulnerable locals to globallymobile elites (p. 7).

This seems to be the way the Bahamian and Puerto Rican governments see the future of their islands: gated Foreign Direct Investment communities, resorts, high-end shops and airports and marinas that can accommodate private jets and yachts. How do regular, working locals fit in this space? Where is the spatial justice in this rezoning, remapping, re-scaping so reminiscent of colonial desires.

\section{References}

Baldwin, J. (2005). The contested beach: Resistance and resort development in Antigua, West Indies. In C. Cartier \& A.

A. Lew (Eds.), Seductions of place: Geographical perspectives on globalization and touristed landscapes (pp. 222-241). New York: Routledge. Retrieved from https://www.taylorfrancis.com/books/978 1134651887

Cartwright-Carroll, T. (2018, June 16). Bannister: No money for Ragged Island restoration this budget cycle. The Nassau Guardian. Retrieved from https://thenassauguardian.com/2018/06/16 /bannister\%E2\%80\%88no-money-forragged-island-restoration-this-budgetcycle/

Bennett, I. (2014). Fragile masculinities: The loss of young men and the pervasive models of masculinity in The Bahamas that encourage them to fail. Caribbean Review of Gender Studies, 8, 43-77. Retrieved from https://sta.uwi.edu/crgs/december2014/jou rnals/CRGS_8_Pgs04378_FragileMasculinities_Bennett.pdf

Bethell-Bennett, I. (2016). Democracy without voice: An examination of land sales and development in The Bahamas. In D. Ramsaran (Ed.), Contradictory existence: Neoliberalism and democracy in the Caribbean (pp. 128-155). Kingston, Jamaica: Ian Randle.
Bethell-Bennett, I. (2010-11). The tragedy of Caribbean space/place. Sargasso, 2010$11(1 \& 2), 105-121$. Retrieved from http://ufdc.ufl.edu/UF00096005/00037/1j

Bethel, N. (2000). Navigations: The fluidity of identity in the post-colonial Bahamas (Unpublished doctoral dissertation) University of Cambridge, Cambridge, England. https://doi.org/10.13140/RG.2.1.2294.896 7

Césaire, A. (2000). Discourse on colonialism. New York, NY: Monthly Review Press.

Cocks, C. (2013). Tropical whites: The rise of the tourist south in the Americas.

Philadelphia: University of Pennsylvania Press.

Dames, C. (2002, September 4). Clifton Cay controversy building steam. The Bahama Journal. Retrieved from http://www.bahamasb2b.com/news/wmvie w.php?ArtID=72

Fanon, F. (1963). The wretched of the earth. New York, NY: Présence Africaine.

Freitag, T. G. (1994). Enclave tourism development: For whom the benefits roll? Annals of Tourism Research, 22, 538-54. https://doi.org/10.1016/01607383(94)90119-8

Galtung, J. (1969). Violence, peace, and peace research. Journal of Peace Research, 6, 167-191.

https://doi.org/10.1177/002234336900600 
301

Glissant, E. (1989). Caribbean discourse. Charlottesville: University of Virginia Press.

Gould K. A., \& Lewis, T. L. (2018). Green gentrification and disaster capitalism in Barbuda. NACLA Report on the Americas, 50, 148-153.

https://doi.org/10.1080/10714839.2018.14 79466

Handy, G. (2018, March 6). Snap election in Antigua puts Barbuda's communal land ownership on the ballot. The Guardian. Retrieved from https://www.theguardian.com/world/2018/ mar/06/antigua-barbuda-electioncommunal-land-ownership

Harvey, D. (2002). The art of rent: Globalization, monopoly and the commodification of culture. Socialist Register, 93-110. Retrieved from http://opa-a2a.org/dissensus/wpcontent/uploads/2008/02/HARVEY_Davi d_The_Art_of_RentGlobalization_Monopoly_and_the_Comm odification_of_Culture1.pdf

Low, S., \& Smith, N. (2006). The politics of public space. London, Eng.: Routledge.

Manoo-Rahming, L. (2010). Immortelle and Bhandaaraa Poems. Hong Kong: Proverse.

Momsen, J. H. (2005). Uncertain images: Tourism development and seascapes of the Caribbean. In C. Cartier \& A. A. Lew (Eds.), Seductions of place: Geographical perspectives on globalization and touristed landscapes (pp. 209-221). New York: Routledge. Retrieved from https://www.taylorfrancis.com/books/978 1134651887

Robinson-Blair, T. (2005, May 23). Residents to demonstrate at Bimini Bay: More trouble for foreign investors as Bahamian protesters intend to imprison work crew and hotel guests. Bahama Journal.

Retrieved from http://www.bahamasb2b.com/news/wmvie w.php?ArtID=5281

Said, E. W. (1978). Orientalism. New York, NY: Pantheon Books.

Saunders, G. (2016). Race and class in the colonial Bahamas, 1880-1960. Gainesville: University Press of Florida.

Sea Bathing Rules, Bahamas. (1938).

Retrieved from http://laws.bahamas.gov.bs/cms/images/L EGISLATION/SUBORDINATE/1938/19 38-0251/SeaBathingRules_1.pdf

Skwiot, C. (2010). The purposes of paradise. Philadelphia: University of Pennsylvania Press.

Smith, N. L. (2007). Whose land is it anyway?: An analysis of the management and distribution of crown land in The Bahamas (Unpublished master's thesis). Massachusetts Institute of Technology, Cambridge, Mass. Retrieved from https://dspace.mit.edu/handle/1721.1/3994 1

Soja, E. W. (2009, September). The city and special justice. Espace et justice = Space and Justice, 1. Retrieved from http://www.jssj.org/article/la-ville-et-lajustice-spatiale/

Soja, E. W. (2010). Seeking spatial justice. Minneapolis: University of Minnesota Press.

Strachan, I. G. (2003). Paradise and plantation: Tourism and culture in the Anglophone Caribbean. Charlottesville: University of Virginia Press.

Thompson, K. A. (2006). An eye for the tropics. Durham, NC: Duke University Press. 
Vagrancy Act, Bahamas (1939). Retrieved

from

http://laws.bahamas.gov.bs/cms/images/L

EGISLATION/PRINCIPAL/1939/1939-

0022/VagrancyAct_1.pdf 